Tropical Journal of Pharmaceutical Research December 2020; 19 (12): 2609-2614

ISSN: $1596-5996$ (print); 1596-9827 (electronic)

(C) Pharmacotherapy Group, Faculty of Pharmacy, University of Benin, Benin City, 300001 Nigeria.

Available online at http://www.tjpr.org

Original Research Article

http://dx.doi.org/10.4314/tjpr.v19i12.19

\title{
Effect of atorvastatin on spermatogenesis in rats: $A$ stereological study
}

\author{
Ekrem Akdeniz ${ }^{1 *}$, Mehmet Emin Onger ${ }^{2}$, Mustafa Suat Bolat ${ }^{3}$, Fatih Firat ${ }^{4}$, Metin \\ Gur $^{3}$, Onder Cinar ${ }^{1}$, Mustafa Bakirtas ${ }^{5}$, Abdullah Acıkgoz ${ }^{6}$, Fikret Erdemir ${ }^{7}$ \\ ${ }^{1}$ Department of Urology, Samsun Training and Research Hospital, Health Sciences University, ${ }^{2}$ Department of Histology and \\ Embryology, School of Medicine, Ondokuz Mayis University, ${ }^{3}$ Urology Clinic, Gazi State Hospital, Samsun, ${ }^{4}$ Tokat State \\ Hospital, Urology Clinic, Tokat, ${ }^{5}$ Department of Pathology, Samsun Training and Research Hospital, Health Sciences \\ University, Samsun, ${ }^{6}$ Department of Urology, School of Medicine, Altinbas University, Istanbul, ${ }^{7}$ Department of Urology, School \\ of Medicine, Gaziosmanpasa University, Tokat, Turkey
}

*For correspondence: Email: ekrem.akdeniz@saglik.gov.tr; Tel: +90 36231115 00; Fax: +90 3622778569

\begin{abstract}
Purpose: To investigate the effects of oral atorvastatin on spermatogenesis in a rat model.

Methods: Rats were equally assigned into control and study groups, the latter receiving atorvastatin (20 $\mathrm{mg} / \mathrm{kg} /$ day). At the end of 12 weeks, spermatogenetic activity was evaluated using stereological and optical fractionator methods. Serum follicle-stimulating hormone (FSH), total testosterone (TT), and luteinizing hormone $(\mathrm{LH})$ levels were measured using micro-ELISA kits. Total cholesterol, triglyceride (TG), low-density lipoprotein cholesterol (LDL - C), and high-density lipoprotein cholesterol levels were also measured by enzymatic colorimetric assays.

Results: Testicular stereological analysis revealed that atorvastatin reduced Sertoli cell numbers ( $p<$ $0.001)$, spermatogonia $(p<0.001)$, spermatocytes $(p<0.001)$, and seminiferous tubule diameters $(p<$ $0.001)$. $L D L-C(p=0.01)$ and $T G(p=0.01)$ values were significantly lower in the study group compared with the control group. There was no significant difference in FSH $(p=0.44), \mathrm{LH}(p=0.48)$, and TT ( $p=0.06)$ levels between the groups.

Conclusion: The findings show that atorvastatin causes deleterious effects on rat spermatogenesis. It should therefore be used with caution in clinical practice owing to its potential adverse effects, especially on male fertility.
\end{abstract}

Keywords: Statin, Atorvastatin, Spermatogenesis, Stereology, Testis

This is an Open Access article that uses a fund-ing model which does not charge readers or their institutions for access and distributed under the terms of the Creative Commons Attribution License (http://creativecommons.org/licenses/by/4.0) and the Budapest Open Access Initiative (http://www.budapestopenaccessinitiative.org/read), which permit unrestricted use, distribution, and reproduction in any medium, provided the original work is properly credited.

Tropical Journal of Pharmaceutical Research is indexed by Science Citation Index (SciSearch), Scopus, International Pharmaceutical Abstract, Chemical Abstracts, Embase, Index Copernicus, EBSCO, African Index Medicus, JournalSeek, Journal Citation Reports/Science Edition, Directory of Open Access Journals (DOAJ), African Journal Online, Bioline International, Open-J-Gate and Pharmacy Abstracts

\section{INTRODUCTION}

The after-effects of drug use, varying from allergic reactions to major organ damage, have increased significantly all over the world [1]. Statins are 3-hydroxy-3-methyl-glutaryl coenzyme-A (HMG Co-A) reductase inhibitors commonly used to reduce the risk of cardiovascular disease. Statin use is growing in association with increases in cardiovascular diseases [2]. Despite being well-tolerated, statins cause side-effects such as muscular pain, hepatic enzyme elevation, and an increased risk of diabetes. Another side-effect of statins 
involves the male reproductive system, although only a few studies to date have investigated this [3].

Experimental rat studies have reported that statins increase DNA fragmentation in sperm and abnormal sperm rates, while reducing spermatozoa motility [4,5]. Similarly, studies of human males have observed that statins significantly compromise semen quality, particularly sperm motility $[6,7]$.

Statins are thought to impair spermatogenesis through various mechanisms. Studies have reported that statins compromise spermatogenesis by causing alterations in sex hormones, particularly testosterone. They also compromise spermatogenesis by causing cell death in testis germ cells, and by damaging sperm motility and morphology through impairment of spermatozoa lipid metabolism [3]. Based on the current literature, it may be concluded that atorvastatin impacts on spermatogenesis. The aim of this study was to investigate the potential effects of atorvastatin on spermatogenesis in rats.

\section{EXPERIMENTAL}

\section{Animals}

Fourteen male Sprague-Dawley rats weighing $340.7 \pm 22.6 \mathrm{~g}$ (range, $306-378 \mathrm{~g}$ ) and aged 9 12 weeks were obtained from the Gaziosmanpasa Experimental Animals Laboratory (Tokat, Turkey). Following a sevenday adaptation period, all rats were assigned to control and study groups. All animals were weighed before the experiment commenced and at the end of the research. On week 12, general anesthesia was applied to fasted rats using $2.5 \%$ isoflurane in nitrous oxide, after which blood samples were collected from the inferior vena cava. All rats were sacrificed with an intraperitoneal lethal dose of ketamine after surgical removal of the testes. All animal experiments were performed in strict accordance with the National Institutes of Health Laboratory Animal Care and Use Guidelines [8]. Approval for the research protocol was granted by Gaziosmanpasa University animal ethics committee (protocol ID: HADYEK - 31).

\section{Atorvastatin dose and administration}

Rats in the control group ( $n=7$ ) and the study group $(n=7)$ were allowed ad libitum access to standard chow and water for 12 weeks. However, rats in the study group also received
$20 \mathrm{mg} / \mathrm{kg} /$ day atorvastatin via pipette, every day in the morning.

\section{Serum/plasma lipid and hormone analysis}

Blood samples were stored in heparin-free tubes for biochemical analysis. Serum samples were first centrifuged $\left(2000 \times \mathrm{g}\right.$ for $15 \mathrm{~min}$ at $\left.+4{ }^{\circ} \mathrm{C}\right)$ and then stored at $-70{ }^{\circ} \mathrm{C}$. The samples were subsequently used for total cholesterol (TC), lowdensity lipoprotein cholesterol (LDL - C), highdensity lipoprotein cholesterol (HDL - C), triglyceride (TG), and glucose measurements using commercial kits in line with the manufacturers' instructions. Sex hormones were determined using rat micro - ELISA kits.

\section{Histopathological examination}

At the end of the experimental period, bilateral scrotal orchiectomy was carried out under general anesthesia. Fixation of testicular specimens was performed using Bouin's solution. The specimens were then embedded in paraffin wax. Three-millimeter sections were prepared, after which the paraffin blocks were cut to a thickness of $5 \mu \mathrm{m}$ with the help of a rotary microtome. Hematoxylin and eosin (H\&E) dye was used to study the testicular structure. The stained sections were examined under a light microscope and were also used for the stereological calculation of seminiferous tubule volumes and numbers of spermatogenic cells.

\section{Stereological analysis of samples}

Histological sections were used to assess mean testicular and tubular volumes using the Cavalieri principle as shown in Figure $1 \mathrm{~A}$ and $\mathrm{B}$, in line with the previous descriptions [9]. The sampling strategies and counting frame size were determined on the basis of a pilot study. As a general procedure in physical dissector studies, section pairs were collected as reference and look-up sections. The study parameters were counted using an unbiased counting frame placed over these sections. The total number of cells was then calculated from the number of cells counted on these sections (Figure $1 \mathrm{C}$ ).

\section{Statistical analysis}

The study data were analyzed on GraphPad InStat (v3.0) (GraphPad, USA) software and were expressed as mean \pm standard deviation. The Friedman and Wilcoxon tests were employed to analyze changes occurring in values. Experimental results were compared between the two groups using the Mann - 
Whitney $U$ test. Statistical significance was set at $p<0.05$.

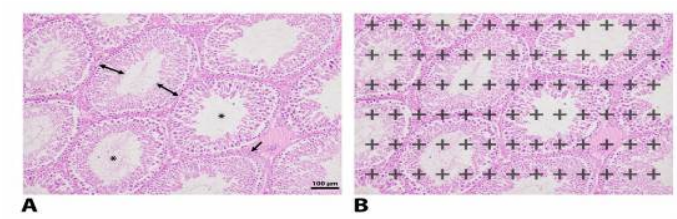

Reference section

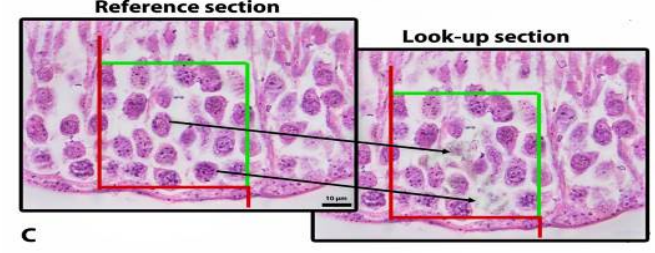

Figure 1: H\&E staining of testicular specimens. (A) the general appearance of the testes, (B) the stereological Cavalieri principle applied to the sections, and (C) the application of the physical dissector cell counting method using section pairs. Double-headed arrows: seminiferous epithelium; arrow: Leydig cells; asterisks: tubular lumens

\section{RESULTS}

\section{General}

The mean pre-study weights of the rats in the study and control groups were $331 \pm 25 \mathrm{~g}$ (range, $306-378 \mathrm{~g}$ ), and $350 \pm 17 \mathrm{~g}$ (range, $318-366$ $\mathrm{g})$, respectively $(p=0.24)$. Mean weights at the end of the experiment were $368 \pm 22 \mathrm{~g}$ (range, $338-406 \mathrm{~g}$ ), and $356 \pm 18 \mathrm{~g}$ (range, $342-396$ $\mathrm{g})$, respectively $(p=0.30)$.

\section{Biochemistry}

The mean postoperative serum follicle stimulating hormone (FSH) levels in the study and control groups were $3.4 \pm 0.3$ and $3.3 \pm 0.3$ $\mathrm{mIU} / \mathrm{mL}(p=0.44)$, and the mean luteinizing hormone $(\mathrm{LH})$ levels were $2.1 \pm 0.1$ and $2.0 \pm 0.2$ $\mathrm{mIU} / \mathrm{mL}(p=0.48)$, respectively. The mean postoperative serum total testosterone (TT) levels were $0.8 \pm 0.6$ and $1.2 \pm 0.8 \mathrm{mmol} / \mathrm{dL}$ in the study and control groups, respectively $(p=$ 0.06). FSH and LH levels were higher in the study group than in the control group, while TT levels were lower. However, none of these differences attained statistical significance (Table 1).

The mean postoperative serum glucose levels in the study and control groups were $168 \pm 16$ $\mathrm{mg} / \mathrm{dL}$ and $151.1 \pm 22(\mathrm{p}=0.12)$, while TG levels were $52 \pm 18.6$ and $93 \pm 19.8 \mathrm{mg} / \mathrm{dL}(p=0.01)$, respectively. TC levels in the study and control groups were $47.7 \pm 6.6 \mathrm{mg} / \mathrm{dL}$ and $50 \pm 7.2(p=$ $0.51)$, respectively. HDL - C levels were $41 \pm 3.7$ and $41.5 \pm 7.8 \mathrm{mg} / \mathrm{dL}(p=0.91)$, and LDL - C levels $3.5 \pm 2.1$ and $10 \pm 4.4 \mathrm{mg} / \mathrm{dL}$, respectively $(p=0.01)$ (Table1).

\section{Histology}

Visible cell loss and undefined cell boundaries were observed in the rat testes from the study group. However, no histological abnormalities were observed in the control group (Figure 2).

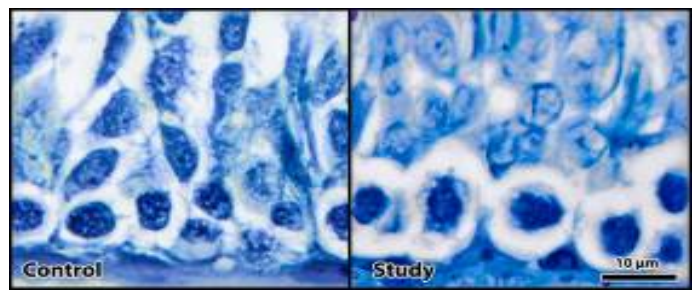

Figure 2: Light microscopic appearance of spermatogenic cells in the control and study groups

\section{Stereology}

Significant decreases occurred in the numbers of Sertoli cells, spermatogonia, and spermatocytes in the study group compared to the control group (Table 2). Mean testis tubule volumes were also significantly lower in the study group compared to the control group $(p<0.001)$ (Table 2).

Table 1: Biochemical variables of the group (mean $\pm S D, n=7$ )

\begin{tabular}{lccc}
\hline Variables & Control group & Study group & $\boldsymbol{P}$-value \\
\hline Blood glucose $(\mathrm{mg} / \mathrm{dL})$ & $151.1 \pm 22$ & $168 \pm 16$ & 0.12 \\
TG $(\mathrm{mg} / \mathrm{dL})$ & $93 \pm 19.8$ & $52 \pm 18.6$ & 0.01 \\
TC $(\mathrm{mg} / \mathrm{dL})$ & $50 \pm 7.2$ & $47.7 \pm 6.6$ & 0.51 \\
HDL - C $(\mathrm{mg} / \mathrm{dL})$ & $41.5 \pm 7.8$ & $41 \pm 3.7$ & 0.91 \\
LDL - C $(\mathrm{mg} / \mathrm{dL})$ & $10 \pm 4.4$ & $3.5 \pm 2.1$ & 0.01 \\
FSH $(\mathrm{mlU} / \mathrm{mL})$ & $3.3 \pm 0.3$ & $3.4 \pm 0.3$ & 0.44 \\
LH $(\mathrm{mlU} / \mathrm{mL})$ & $2.0 \pm 0.2$ & $2.1 \pm 0.1$ & 0.48 \\
TT $(\mathrm{mmol} / \mathrm{dL})$ & $1.2 \pm 0.8$ & $0.8 \pm 0.6$ & 0.06 \\
\hline
\end{tabular}

Key: FSH, Follicle-stimulating hormone; HDL - C, High-density lipoprotein cholesterol; TT, Total testosterone; LDL - C, Low-density lipoprotein cholesterol; LH, Luteinizing hormone; TC, Total cholesterol; TG, Triglyceride 
Table 2: Stereological results (mean $\pm S D, n=7$ )

\begin{tabular}{lccc}
\hline Variable & Control group & Study group & $P$-value \\
\hline Testicular volume $\left(\mathrm{x} 10^{2}, \mathrm{~mm}^{3}\right)$ & $291.43 \pm 8.40$ & $282.71 \pm 6.28$ & 0.18 \\
Mean tubular volume $\left(\mathrm{cm}^{3}\right)$ & $0.75 \pm 0.56$ & $0.51 \pm 0.55$ & $<0.001$ \\
Total number of Sertoli cells $\left(\times 10^{6}\right)$ & $4.882 \pm 146$ & $3.011 \pm 118$ & $<0.001$ \\
Total number of sermatogonia $\left(\times 10^{6}\right)$ & $1.25 \pm 0.10$ & $0.97 \pm 0.08$ & $<0.001$ \\
Total number of spermatocytes $\left(\times 10^{6}\right)$ & $2.63 \pm 0.93$ & $1.76 \pm 0.11$ & $<0.001$ \\
\hline
\end{tabular}

\section{DISCUSSION}

This study employed a stereological technique to investigate the effect of atorvastatin on spermatogenesis in the rat testis. Stereological methods provide essential quantitative data for the evaluation of morphological characteristics in the rat testis. The total volumes of the testes, interstitial tissues and germinal epithelium, seminiferous tubules, the diameter, length, and cross-sectional area of tubules, numbers of myoid, Leydig, and Sertoli cells, and the numbers of spermatids, spermatocytes and spermatogonia can all be calculated using this method and simulated throughout the organ [9]. Atorvastatin at $20 \mathrm{mg} / \mathrm{kg}$ per day for 12 weeks caused a significant deterioration in spermatogenesis in the present study. It also significantly reduced serum TG and LDL - $C$ concentrations.

Infertility is associated with male-related factors, such as varicocele, undescended testis, genital infections, genetic causes, hormonal disorders, and obstructive pathologies. Other, rarer causes of infertility include radiation, surgical procedures, environmental factors, occupation, and medications [10]. The use of drugs to combat chronic diseases has increased dramatically in recent years. Numerous studies have investigated the effects of calcium channel blockers, valproate, sulfasalazine, antihyperlipidemics, acetylsalicylic acid, spironolactone, cimetidine, serotonin reuptake inhibitors, and antibiotics on sperm parameters [11]. Similarly to those drugs, statins are also capable of affecting semen parameters. Although the use of statins has increased recently, very few data are available concerning their effects on spermatogenesis [3].

Testosterone is the basic hormone essential for spermatogenesis. The testosterone-dependent phase of spermatogenesis, known as spermiogenesis (progression from round to elongated spermatids), constitutes the final phase of spermatogenesis. Testosterone is also essential for the transition from spermatogonia $A$, an early stage of spermatogenesis, to spermatogonia B. Testosterone contributes to the survival of spermatocytes and spermatids through anti-apoptotic mechanisms [12]. All steroid hormones are synthesized from cholesterol, and testosterone levels may decline under conditions of reduced cholesterol concentrations [13-16]. A decrease in testosterone levels may be associated with decreased spermatogenesis. The hypothesis in the present study was that by reducing cholesterol, atorvastatin might lower testosterone levels and subsequently impair spermatogenesis.

The study findings showed that TT levels decreased by $38.5 \%$ in the study group compared to the control group. Similarly, stereological analysis also demonstrated signifycant decreases in numbers of spermatogonia, spermatocytes, and Sertoli cells in the study group. The decreased seminiferous tubule volume observed in the study group may probably be attributed to seminiferous tubule atrophy. Clinical studies, albeit fewer in number, have also investigated the effect of statins on testis functions. Atorvastatin also significantly affected semen parameters in another human study in which $10 \mathrm{mg} /$ day of atorvastatin was administered every day for five months to 17 normospermic male patients with a mean age of 24 years. It reduced sperm vitality and total spermatozoa numbers, while increasing morphological abnormalities.

Atorvastatin also exhibited an adverse effect on the reproductive system by reducing levels of acid phosphatases, a-glucosidase and Lcarnitine in seminal fluid [7]. Another study involving pre-pubertal rats examined the effect of rosuvastatin on the reproductive system. The authors reported a decrease in serum testosterone levels and delayed puberty in rats receiving rosuvastatin. A significant decrease in mature spermatids and daily sperm production numbers was also determined in rats that received rosuvastatin, indicating a significant adverse effect on sperm parameters [4]. In the present study, atorvastatin administration adversely affected spermatogenesis in the study group compared to the control group. However, the mechanism behind these effects is still unclear.

A minimal decrease in intratesticular testosterone has previously been observed, with no change in systemic hormone levels, in young patients using atorvastatin [7]. Similarly, in the present study, 
TT levels decreased in rats receiving atorvastatin, although this was not statistically significant. The administration of $40 \mathrm{mg}$ pravastatin and placebo has also been shown to cause no change in TT levels after 3 months [17]. In another study, even $20 \mathrm{mg}$ atorvastatin administration daily for 3 months produced no change in TT levels in 16 male patients with type 2 diabetes [18]. However, numerous studies have reported statistically significant reductions in TT levels in humans following statin use [3]. Since various factors affect TT levels, different studies have elicited differing results. The decrease in TT levels noticed in experimental animal studies may also be associated with different durations of drug administration.

Stereological analysis in the present study revealed significantly impaired spermatogenesis in the testes of rats receiving atorvastatin for 12 weeks at $20 \mathrm{mg} / \mathrm{kg} /$ day. Atorvastatin has been used at between 10 and $50 \mathrm{mg} / \mathrm{kg} /$ day in previous animal studies [3]. It should be remembered that, similarly to other drugs, the effect of atorvastatin will vary depending on the dose employed.

\section{CONCLUSION}

This study shows that the administration of atorvastatin, one of the most commonly prescribed medications worldwide, particularly for the treatment of cardiovascular disease, resulted in deleterious stereological effects on spermatogenesis. Statin therapy, with its potential side-effects on spermatogenesis, should therefore be prescribed with great care, particularly in young male patients. However, further experimental research, and particularly human studies, are now needed to confirm these outcomes.

\section{DECLARATIONS}

\section{Conflict of interest}

No conflict of interest is associated with this work.

\section{Contribution of authors}

We declare that this work was done by the authors named in this article and all liabilities pertaining to claims relating to the content of this article will be borne by the authors. E.A. and F.E. were responsible for the experiments and experimental design; F.F., M.B., and M.E.O. performed the experiments; E.A., M.B. and M.E.O. analyzed the data; M.E.O., A.A., O.C.,
M.G and M.S.B. contributed reagents/materials/ analysis tools; and E.A. and F.E. produced the manuscript. All authors read the article and approved the final version of the manuscript.

\section{Open Access}

This is an Open Access article that uses a funding model which does not charge readers or their institutions for access and distributed under the terms of the Creative Commons Attribution License (http://creativecommons.org/licenses/by/ 4.0) and the Budapest Open Access Initiative (http://www.budapestopenaccessinitiative.org/rea d), which permit unrestricted use, distribution, and reproduction in any medium, provided the original work is properly credited.

\section{REFERENCES}

1. Gandhi TK, Burstin HR, Cook EF, Puopolo AL, Haas JS, Brennan TA, Bates DW. Drug complications in outpatients. J Gen Intern Med 2000; 15(3): 149-154.

2. Rosenson RS, Farkouh ME, Mefford M, Bittner $V$, Brown $T M$, Taylor B, Monda KL, Zhao $H$, Dai $Y$, Muntner $P$. Trends in Use of High-Intensity Statin Therapy After Myocardial Infarction, 2011 to 2014. J Am Coll Cardiol 2017; 69(22): 2696-2706.

3. Banihani SA. Effect of statin on semen quality characteristics. Andrologia 2020; 52(6): e13592.

4. Leite GA, Rosa Jde L, Sanabria M, Cavariani MM, Franci $J A$, Pinheiro PF, Kempinas Wde G. Delayed reproductive development in pubertal male rats exposed to the hypolipemiant agent rosuvastatin since prepuberty. Reprod Toxicol 2014; 44: 93-103.

5. Leite GAA, Sanabria M, Cavariani MM, Anselmo-Franci $J A$, Pinheiro PFF, Domeniconi RF, Kempinas WG. Lower sperm quality and testicular and epididymal structural impairment in adult rats exposed to rosuvastatin during prepuberty. J Appl Toxicol 2018; 38(6): 914-929.

6. Cai T, Mondaini N, Mazzoli S, Bartoletti R. A possible negative effect of co-administered amlodipine and atorvastatin on semen volume and spermatozoa in men. J Pharm Pharmacol 2008; 60(11): 1431-1432.

7. Pons-Rejraji H, Brugnon F, Sion B, Maqdasy S, Gouby G, Pereira B, Marceau G, Gremeau AS, Drevet J, Grizard G, Janny L, Tauveron I. Evaluation of atorvastatin efficacy and toxicity on spermatozoa, accessory glands and gonadal hormones of healthy men: a pilot prospective clinical trial. Reprod Biol Endocrinol 2014; 12: 65.

8. Council NR: Guide for the care and use of laboratory animals: National Academies Press; 2010.

9. Noorafshan A. Stereology as a valuable tool in the toolbox of testicular research. Ann Anat 2014; 196: 5766.

Trop J Pharm Res, December 2020; 19(12): 2613 
10. Jungwirth A, Giwercman A, Tournaye H, Diemer T, Kopa Z, Dohle G, Krausz C; European Association of Urology Working Group on Male Infertility. European Association of Urology guidelines on Male Infertility: the 2012 update. Eur Urol 2012; 62(2): 324-332.

11. Semet M, Paci J, Saïas-Magnan, Metzler-Guillemain C, Boissier R, Lejeune $H$, Perrin J. The impact of drugs on male fertility: a review. Andrology 2017; 4: 640-663.

12. Shiraishi $K$, Matsuyama $H$. Gonadotoropin actions on spermatogenesis and hormonal therapies for spermatogenic disorders. Endocr J 2017; 64: 123-131.

13. Klinefelter GR, Laskey J, Amann RP. Statin drugs markedly inhibit testosterone production by rat Leydig cells in vitro: implications for men. Reprod Toxicol 2014; 45: 52-58.

14. Beverly BE, Lambright CS, Furr JR, Sampson H, Wilson, VS, McIntyre BS, Gray Jr L. E. Simvastatin and dipentyl phthalate lower ex vivo testicular testosterone production and exhibit additive effects on testicular testosterone and gene expression via distinct mechanistic pathways in the fetal rat. Toxicological Sciences 2014; 141: 524-537.

15. Hall SA, Page ST, Travison TG, Montgomery RB, Link $C L$, McKinlay JB. Do statins affect androgen levels in men? Results from the Boston area community health survey. Cancer Epidemiol Biomarkers Prev 2007; 16: 1587-1594.

16. Hsieh CJ, Huang B. Rosuvastatin decreases testosterone levels but not sexual function in men with type 2 diabetes. Diabetes Res Clin Pract 2016; 120: 81-88.

17. Bohm M, Herrmann W, Wassmann S, Laufs $U$, Nickenig G. Does statin therapy influence steroid hormone synthesis? Z Kardiol 2004; 93: 43-48.

18. Santini SA, Carrozza C, Lulli P, Zuppi C, CarloTonolo G, Musumeci S. Atorvastatin treatment does not affect gonadal and adrenal hormones in type 2 diabetes patients with mild to moderate hypercholesterolemia. $\mathrm{J}$ Atheroscler Thromb 2003; 10: 160-164. 